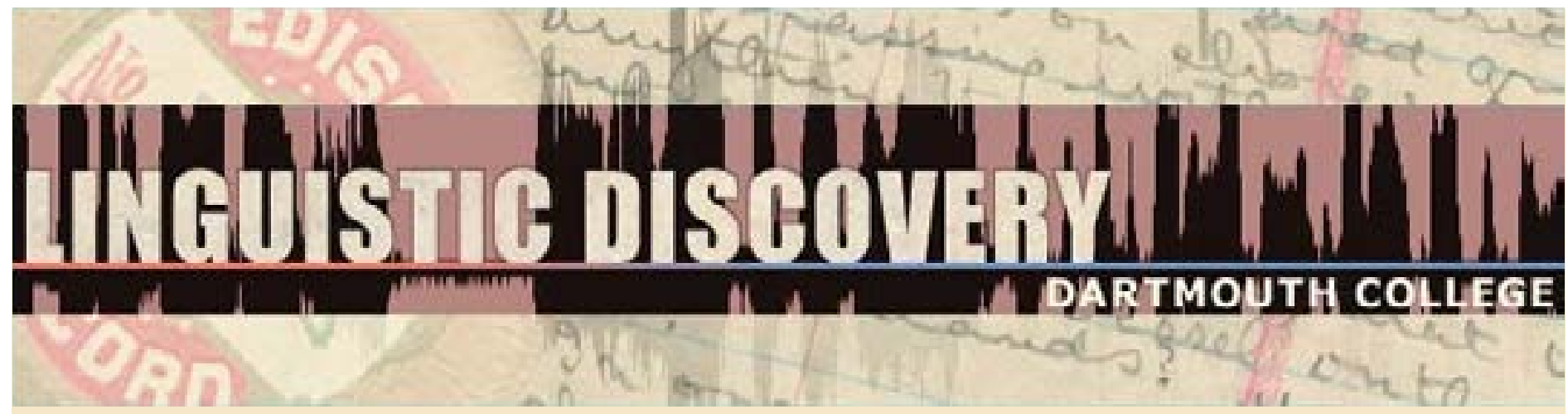

\begin{tabular}{|l|}
\hline Volume 9 \\
Issue 2 \\
2011 \\
\hline
\end{tabular}

\title{
Evidentiality in Tsezic Languages
}

Zaira Khalilova

Max Planck Institute for Evolutionary Anthropology, Leipzig

doi: 10.1349/PS1.1537-0852.A.393

url: http://journals.dartmouth.edu/cgi-bin/WebObjects/ Journals.woa/1/xmlpage/1/article/393

\section{Linguistic Discovery}

Published by the Dartmouth College Library Copyright to this article is held by the authors. ISSN 1537-0852 linguistic-discovery.dartmouth.edu 


\section{Evidentiality in Tsezic Languages

\author{
Zaira Khalilova
}

Max Planck Institute for Evolutionary Anthropology, Leipzig

\section{Introduction}

\subsection{Tsezic languages}

The Tsezic languages belong to the Nakh-Daghestanian (Northeast Caucasian) language family. The Tsezic languages can be divided into the West Tsezic sub-branch, including Tsez, Hinuq and Khwarshi, and the East Tsezic sub-branch, including Bezhta and Hunzib. All five Tsezic languages are spoken mostly in the south of Daghestan.

The Nakh-Daghestanian language family

$\underline{\mathrm{Nakh}}$

(Chechen, Ingush; Tsova-Tush)

Dagestanian

Avar-Andi (Avar; Andi, Godoberi, Bagvalal, Chamalal, Tindi, Botlikh, Akhvakh, Karata)

Tsezic (Tsez, Hinuq, Khwarshi; Hunzib, Bezhta)

Lak

Dargi (Akusha, Urakhi, Tsudakhar, Kaytag, Kubachi, Chirag, Mehweb)

Lezgic (Lezgian, Tabasaran, Agul; Rutul, Tsakhur; Kryz, Budukh; Archi; Udi)

Khinalug

In terms of the most common morphosyntactic features of Tsezic languages, they are verb-final languages, with no rigid word order. Tsezic languages are dependent-marking ergative languages. Tsezic languages have an elaborate case system. All Tsezic languages have gender agreement, which varies from 4 to 5 genders, and genders are employed to indicate crossreferencing of arguments on the verb. The agreement is always with the Absolutive argument, and only vowel-initial verbs have slots for agreement.

\subsection{Background to the study}

A number of languages in the world grammaticalize the specification of the source of information, i.e. they systematically specify how the information was obtained, e.g. visually, or whether information was inferred or learned from someone. A grammatical category such as this is called evidentiality (Aikhenvald and Dixon 2003: 2).

The main evidential distinctions are made between 'firsthand' and 'non-firsthand', corresponding to direct and indirect sources of information, respectively. Many languages also mark 'inferential', which is based on the speaker's inference of some action on the basis of visible traces of the event, and 'reported' (also called 'secondhand information'), where the source of information is based on some other person's statement. This paper provides the main patterns relevant to the typological study of the category of evidentiality with special focus on the Tsezic languages. 
Most often, the category of evidentiality overlaps with tense-aspect systems. For instance, Balkan Slavic has a past tense suffix which expresses evidentiality (Friedman 1986: 171). In Tsezic languages evidentiality is also mixed with the tense-aspect system.

Evidentiality may also have mirative overtones, i.e. marking a speaker's surprise at new and unexpected information.

Evidentiality is common cross-linguistically, but is particularly widespread in the western regions of the U. S., the Himalayas, and the area around the Black Sea including the Caucasus (Willet 1988:64).

\section{Evidentiality in the Tsezic languages ${ }^{1}$}

Tsezic languages, like many other Daghestanian languages, have a number of devices to express the meaning of evidentiality. The evidential categories distinguish between witnessed (direct), unwitnessed (indirect), inferential, and reported evidence.

West Tsezic and East Tsezic languages have different patterns to express evidential distinctions $^{2}$. In the East Tsezic branch the carrier of evidential distinctions are the Preterite, a synthetic form which is used to mark witnessed events (direct evidential), and the Perfect, an analytical form (though sometimes the copula within the analytical form can be omitted) used for unwitnessed events (indirect evidential). In the West Tsezic languages, in the past tense, there is a morphological opposition between Past witnessed (direct evidential) and Past unwitnessed (indirect evidential) forms; both are synthetic forms.

In Tsezic languages the direct evidential expresses an event that has been visually perceived by the speaker, and the indirect evidential refers to an event that has not been seen by the speaker; the indirect evidential forms are most often used in narrative contexts. Thus, the main distinction is between visually and non-visually acquired information.

In declarative sentences the information source of the speaker is encoded, while in interrogative sentences it is the information source of the addressee/hearer. So, the category of evidentiality is a grammatical category, i.e. every past sentence is obligatorily marked for evidentiality to show how the information was obtained.

All Tsezic languages can express inferential evidentiality, i.e. an inference made by the speaker based on visible traces of an event to which the speaker was not a direct witness. The reported evidential uses the quotative particle (e.g. Khwarshi $\lambda u n$ ) to indicate that the information was learned from someone else, while the narrative particle (e.g. Tsez $\lambda a x)$ is used in narratives.

\footnotetext{
${ }^{1}$ The main sources of information for this paper are my fieldwork notes (Khwarshi, Bezhta, partially Hunzib), a grammar on Hunzib (van den Berg 1995), and personal communication with language specialists (on Bezhta with Madzhid Khalilov, on Tsez with Bernard Comrie and Arsen Abdullaev, on Khwarshi with Raisat Karimova, on Hinuq with Diana Forker).

${ }^{2}$ The distinction between witnessed and unwitnessed past forms in Tsezic languages has been noted by Bokarev (1959), who discusses Past I and Past II forms, which stand for witnessed and unwitnessed past respectively. Imnajšvili (1963: 180) for Tsez, Hinuq and Khwarshi discusses the Past Definite and the Past Indefinite, which are used for witnessed and unwitnessed events. Klimov (1978: 69) mentions the Recent Past (witnessed) and the Remote Past (unwitnessed).
} 


\subsection{The Witnessed and Unwitnessed distinction in East Tsezic}

The Past witnessed (direct evidential) indicates that the event was directly witnessed by the speaker, i.e. the speaker was an eyewitness to the event:

(1) Bezhta

isi-s kayay $\quad \mathrm{y}-\mathrm{o}^{\mathrm{n}} \mathrm{q}$ 'o-yo.

sister-GEN1 letter(IV) IV-come-PRET

'The sister's letter has arrived.' (the speaker saw this)

(2) Hunzib (van den Berg 1995: 84)

\begin{tabular}{|c|c|}
\hline $\begin{array}{l}\alpha b u-l^{3} \\
\text { father-ERG }\end{array}$ & $\begin{array}{l}\text { ož-di-i } \\
\text { boy-OBL-DAT }\end{array}$ \\
\hline
\end{tabular}

'The father struck his son.' (the speaker saw this)

The Past unwitnessed (indirect evidential) indicates that the described event was not directly witnessed by the speaker:

(3) Bezhta

$\begin{array}{lllll}\text { maduhanlas } & \text { boxalāhiyo } & \text { wo } & \text { b-uro-na } & \text { gey. } \\ \text { neighbor.GEN1 } & \text { savage } & \text { dog(III) } & \text { III-die-PFV.CVB } & \text { be.PRS } \\ \text { 'The neighbor's } & \text { savage dog is } & \text { dead.' (the } & \text { speaker did not see it die) }\end{array}$

(4) Hunzib (van den Berg 1995: 101)

$\begin{array}{llll}\text { ož-di-l } & \lambda \text { 'oq'ol } & \text { guk'-un } & \text { lo. } \\ \text { boy-OBL-ERG } & \text { hat(IV) } & \text { put-PFV.CVB } & \text { be(IV) }\end{array}$

'The boy has put on his hat.' (the speaker did not see this $)^{4}$

Unwitnessed forms often acquire additional connotations when used with the first person. The unwitnessed forms in Tsezic languages have a lack of consciousness effect with the first person, which means that the speaker is not aware of the event in which he/she took part. Such contexts often describe situations where the speaker was drunk or was unconscious or was asleep, and he/she could not remember the event. The Hunzib Perfect is also used with the first person in restricted contexts (i.e. in contexts with a presupposed lack of consciousness or lack of control), e.g. during sleep (6) (contrary to the claim in van den Berg (1995: 101) that in Hunzib the Perfect is never used with the first person).

(5) Bezhta

$\begin{array}{llllll}\text { huł } & \text { do } & \text { teli } & \text { liso } & \text { y-oh-na } & \text { gey. } \\ \text { yesterday } & \text { 1SG.ABS } & \text { much } & \text { dance(IV) } & \text { IV-do-PFV.CVB } & \text { be.PRS }\end{array}$

'Apparently I danced a lot yesterday.' (as my feet are aching today)

\footnotetext{
$3 / \alpha /$ is lower and more retracted than IPA [a] (van den Berg 1995: 21).

${ }^{4}$ The meaning of this example was also confirmed by a Hunzib speaker.
} 
(6) Hunzib

$$
\begin{array}{llll}
\text { mì } \lambda \text { ał } & \text { do } & \text { yiy-an } & \text { lo. } \\
\text { dream.INTER } & \text { 1SG.ABS } & \text { cry-PFv.CVB } & \text { be(II) } \\
\text { 'I (female) cried in my dream.' (I don't remember this, but someone told me this) }
\end{array}
$$

The distribution of witnessed and unwitnessed forms also depends on whether it is an autobiographical narration or a traditional (or fictional) narration. Simple narrations are memories and autobiography. In such contexts the Past witnessed form is mostly used since the speaker tells a story in which he/she has participated in person, i.e. the speaker is a direct witness to the narrated event.

(7) Bezhta

$\begin{array}{llll}\text { hogo zaman } & \text { zuq'o-yo } & \text { kotakalda } & \text { q'aridab } \\ \text { that time } & \text { be-PRET } & \text { very } & \text { poor }\end{array}$

A context such as 'I was born...' where the speaker cannot remember his/her birth is expressed with the unwitnessed forms in East Tsezic.

(8) Hunzib

$\begin{array}{llll}\text { do } & \text { y-aqu-n } & \text { lo } & \text { hon } \lambda \text { 'oda. } \\ \text { 1SG.ABS } & \text { II-become-PFV.CVB } & \text { be(II) } & \text { in.Hunzib } \\ \text { 'I (female) } & \text { was born in Hunzib.' } & & \end{array}$

(9) Bezhta

$\begin{array}{llllll}\text { do } & \varnothing \text {-aq-na } & \text { gey } & \text { hazay-na } & \text { äčena } & \text { č'it'-na } \\ \text { 1SG.ABS } & \text { I-become-PFV.CVB } & \text { be.PRS } & \text { thousand-AND } & \text { nine } & \text { hundred-AND }\end{array}$

finayig-la $\quad \lambda$ i?.

fifty-GEN2 year.IN.ESS

'I (male) was born in 1953.' [Biography.001]

Traditional or fictional narratives are legends, fairy-tales, and the like, which are mostly expressed with the Past unwitnessed forms. Traditional narratives usually start with the phrase 'once upon a time' (literally 'there was there was not'), which is marked with Past unwitnessed forms. For Hunzib the repetition of the verbal phrase as in (11) is the traditional beginning of a tale (van den Berg 1995: 162). The story starts and ends in Past unwitnessed forms:

(10) Bezhta

$\begin{array}{llllll}\text { a. zuq'o-na } & \text { gey } & \text { zuq'o-na } & \text { gäPä } & \text { hos } & \text { qartay. } \\ \text { be-PFV.CVB } & \text { be.PRS } & \text { be-PFV.CVB } & \text { be.NEG } & \text { one } & \text { witch }\end{array}$

'Once upon a time there was a witch.' [qartay.01]

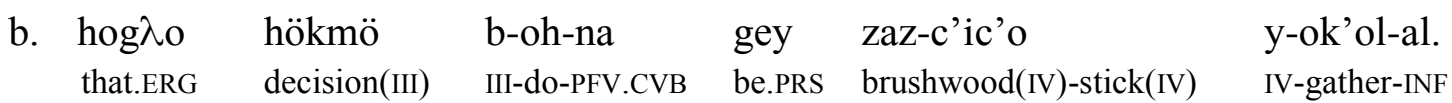

'She decided to go to gather some brushwood.' [qartay.02] 
(11) Hunzib (van den Berg 1995: 162)

$\begin{array}{lllll}\text { zuq'u-n } & \text { lo } & \text { zuq'u-n } & \text { lo } & \text { Malla.nasrudin. } \\ \text { be-PFV.cVB } & \text { be(I) } & \text { be-PFv.cvB } & \text { be(I) } & \text { Malla.nasrudin(I) } \\ \text { 'Once upon a time there lived Mullah Nasredin.' } & \text { [Sentence1] }\end{array}$

(12) Bezhta

q'ac'c'olaqas okko-na y-oc'in-na $\quad$ Ø-e $e^{\mathrm{n} h}$-na $\quad$ gey $\quad$ Malla.nasrudin

all.POSS.ABL money(IV)-AND IV-fill-PFV.CVB $\quad$ I-send-PFV.CVB $\quad$ be.PRS Malla.nasrudin(I)

bi $\lambda$ oya.

house.NEAR

'Having filled (sack) with everybody's money, Malla Nasrudin was sent home.' [Malla Nasrudin.023]

(13) Hunzib (van den Berg 1995: 233)

\begin{tabular}{|c|c|c|c|c|c|}
\hline $\begin{array}{l}\dot{i}^{n} c^{\prime} c^{\prime} u \\
\text { new }\end{array}$ & $\begin{array}{l}\text { aqe-n } \\
\text { wife(II)-AND }\end{array}$ & $\begin{array}{l}\text { y-əq'ə-n } \\
\text { II-lead-PFV.cVB }\end{array}$ & $\begin{array}{l}\text { bet'erbaqi } \\
\text { household(IV) }\end{array}$ & $\begin{array}{l}\text { b-uwo-n } \\
\text { IV-do-PFV.cVB }\end{array}$ & $\begin{array}{l}\text { əg-ra-n } \\
\text { that-PL-AND }\end{array}$ \\
\hline & & & & & \\
\hline
\end{tabular}

'He married a new wife and they stayed there making a living.' [Sentence.96]

The storyteller usually continues narrating in the Past unwitnessed forms throughout the whole story since he/she was not a witness to the events that are being narrated, as in (14). However the use of present tense and past witnessed forms is also possible and such usage functions as a historic present (the present tense used for past time reference), which renders the description of the narrated events more vivid.

(14) Bezhta

$\begin{array}{lllllll}\text { a. } & \varnothing-\mathrm{e}^{\mathrm{n}} \lambda{ }^{\prime} \mathrm{e}-\mathrm{s} & \text { Malla.nasrudin } & \text { mužmar } & \text { wodi-? } & \text { kak } & \text { y-ow-al } \\ \text { I-go-PRS } & \text { Malla.nasrudin(I) } & \text { Friday } & \text { day.OBL-IN.ESS } & \text { prayer(IV) } & \text { IV-do-INF }\end{array}$

maždik-iya-?.

mosque-OBL-IN.ESS

'Malla Nasrudin went to make a Friday prayer to the mosque.' [Malla Nasrudin.001]

b. kak-na y-oh-na, mužmar liq'oł, badloyoy

prayer(IV)-AND IV-do-PFV.CVB $\quad$ Friday.prayer finish.ANTR other.COMIT

gisak-sa huli.

go.out-PRS he.ABS

'When the prayer was over, he went out with others.'[Malla Nasrudin.002] 
The other usage of the indirect evidential forms in Bezhta and in Hunzib is to express inferential meaning, which includes the visible result of the event, i.e. the speaker has direct evidence for the event but has not witnessed this event himself/herself. This is seen in the Bezhta example (15), in which the speaker sees the empty plates and then makes an inference that the boys have eaten all the khinkal, i.e. the speaker did not see the boys eating, but the speaker does see the result of their eating, the empty plates. The Hunzib sentence (16) illustrates that though the speaker was not a direct witness to the event, i.e. the speaker did not see the brothers come, the speaker inferred the event based on some related facts or some results of this event, e.g. seeing the shoes of the brothers in the corridor.

(15) Bezhta

öždää q'ac'c'o xink' m-ün q-na gey.

boy.PL.ERG all khinkal(III) III-eat-PFV.CVB be.PRS

'The boys have eaten all the khinkal.' (the speaker sees the empty plate)

(16) Hunzib

diyo is-na m-aq'e-n lo.

1SG.GEN1 brother-PL HPL-come-PFV.CVB be(HPL)

'My brothers have come.' (the speaker sees his brothers' shoes in the corridor, but has not seen his brothers yet)

\subsection{The Bezhta and Hunzib Perfect}

The verbal forms marking indirect evidence in Bezhta and Hunzib are actually Perfect, where the perfect denotes a situation occurring prior to the reference time and is relevant to the situation at the reference time (Bybee et al. 1994: 61-69). Thus, East Tsezic has the Perfect tense which is used to refer to indirect evidential and perfect meanings (Perfect is considered a languagespecific category).

It is interesting that in Bezhta the perfective converb is obligatorily combined with an auxiliary for the Perfect, whereas for the indirect evidential the perfective converb can occur on its own, i.e. the auxiliary can be optionally omitted. Similar usage of the Perfect is found elsewhere, for instance, in Bulgarian, where the construction without an auxiliary is treated as being marked for evidentiality, viz. for reportedness (Friedman 1986: 175).

The use of the East Tsezic Perfect is illustrated in (17), where it is the situation of eating which is relevant to the moment of speech.

(17) Bezhta [answer to the invitation to have a dinner]

$\begin{array}{lll}\text { do } & \text { y-eš-na } & \text { gey. } \\ \text { 1SG.ABS } & \text { II-eat-PFV.cVB } & \text { be.PRS } \\ \text { 'I (female) } & \text { have already eaten.' }\end{array}$

(18) Hunzib (van den Berg 1995: 101)

$\begin{array}{llll}\text { o } \lambda \mathrm{u}-1 & \text { kayar } & \text { čax-en } & \text { li. } \\ \text { that.OBL-ERG } & \text { letter(v) } & \text { write-PFV.CVB } & \text { be(v) }\end{array}$

'(S)he has written a letter.' 


\subsection{The Witnessed and Unwitnessed distinction in West Tsezic}

Now we move to expressions of evidentiality in West Tsezic languages. Khwarshi, Tsez, and Hinuq have morphologically marked evidential forms for Past witnessed (19a, 20a, 21a) and for Past unwitnessed (19b, 20b, 21b).

(19) Khwarshi

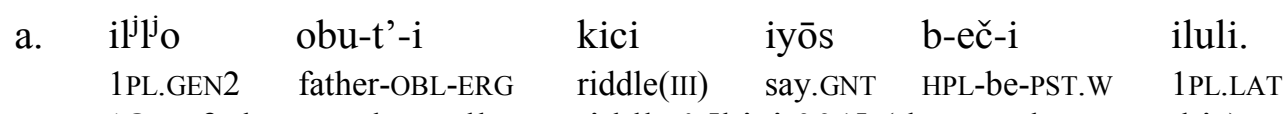

'Our father used to tell us a riddle.' [kici.001] (the speaker saw this)

$\begin{array}{lllll}\text { b. } & \text { m-e } \lambda \text { '-un } & \text { šayt'an } & \text { q'udu-n } & \text { b-eč-zaha-li. } \\ \text { III-go-PST.UW } & \text { devil(III) } & \text { down-AND } & \text { HPL-be-LOc.CVB-LAT }\end{array}$

'The devil went to the place where (people) were sitting.' [kici.002] (the speaker did not see this)

(20) Tsez (Comrie \& Polinsky 2007: 338)
a. obiy-ā madina-r k'icu
father-ERG Madina-LAT strawberry(II) II-buy-PST.W
'Father bought strawberries for Madina.' (the speaker saw this)
b. obiy-ā madina-r k'icu y-is-no.
father-ERG Madina-LAT strawberry(II) II-buy-PST.UW
'Father bought strawberries for Madina.' (the speaker did not see this)

(21) Hinuq

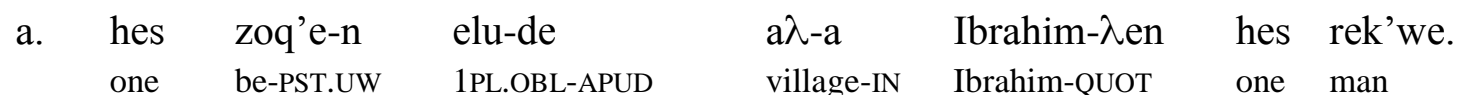

'One man, called Ibragim, lived in our village.' [Ibragim.002] (the speaker did not see this)

b. hayi-̌̌ dayarka-be-n b-i $\lambda$ 'i-n, $\quad \gamma \mathrm{i} \quad$ t'ot'-iš.

there-ABL1 milkmaid-PL-AND HPL-go-PFV.CVB milk milk-PST.W

'Then the milkmaids came from there and milked (the cow).' (the speaker saw this)

In simple narrations, the Past witnessed form is mostly used.

(22) Khwarshi

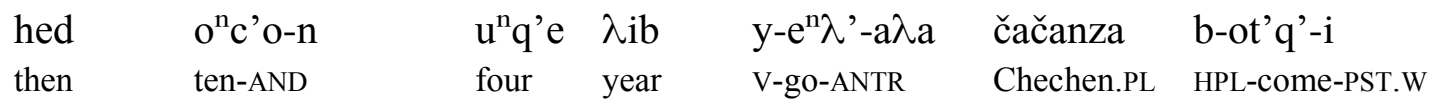

\footnotetext{
${ }^{5}$ Examples with references come from the sources mentioned; other examples are taken from the Toolbox corpus of Khwarshi, Tsez, Hinuq, and Bezhta texts.
} 
žohoq'emil žillo č'ido- $\lambda$ 'o-li.

backwards 3PL.GEN2 territory-SUP-LAT

'Then when fourteen years passed, the Chechens came back to their place.' (the speaker (an old man) was a witness to the event)

(23) Hinuq

$\begin{array}{llllll}\begin{array}{l}\text { Abdurahman- } \lambda \text { en } \\ \text { Abduraxman-QUOT }\end{array} & \begin{array}{l}\text { e } \lambda \text { i-yo-, } \\ \text { say-IMPF.CVB }\end{array} & \begin{array}{l}\text { zoq'e-s } \\ \text { be-PST.w }\end{array} & \begin{array}{l}\text { oc'eno } \\ \text { ten }\end{array} & \begin{array}{l}\text { q'ono } \\ \text { two }\end{array} & \begin{array}{l}\lambda \text { ebu } \\ \text { year }\end{array} \\ \text { sekretar-4i } & \text { r-u-S } & \text { C'unt'a } & \text { rayon-mo-z. } & \\ \text { secretary-AS } & \text { V-do-PST.w } & \text { Tsunta } & \text { district-OBL-DAT } & \\ \text { 'Abduraxman worked as a secretary at Tsunta district for twelve years.' }\end{array}$

The unwitnessed forms used with the first person provide a lack of consciousness effect.

(24) Khwarshi

$\begin{array}{lllll}\text { nišo-ho } & \lambda \text { us-un } & \text { y-eč-a } \lambda \mathrm{a}, & \text { do } & \text { y-uc'-un. } \\ \text { night-AD } & \text { sleep-PFV.CVB } & \text { II-be-ANTR } & \text { 1SG.ABS } & \text { II-get.cold-PST.UW }\end{array}$

'Apparently at night I (female) caught a cold.' (because in the morning I had a running nose and fever)

(25) Tsez

di dey kodi b-eč'-no.

1SG.ERG 1SG.GEN1 hair(III) III-cut-PST.UW

'I cut my hair.' ( I don’t remember this, maybe because I was drunk-)

It is interesting to note that, unlike East Tsezic, West Tsezic uses witnessed past in the context 'I was born ...' (26), (27). In such a context the unwitnessed forms are also possible, but this implies that the speaker is not sure when he/she was born. Older people often use unwitnessed forms in this context. ${ }^{6}$

(26) Hinuq

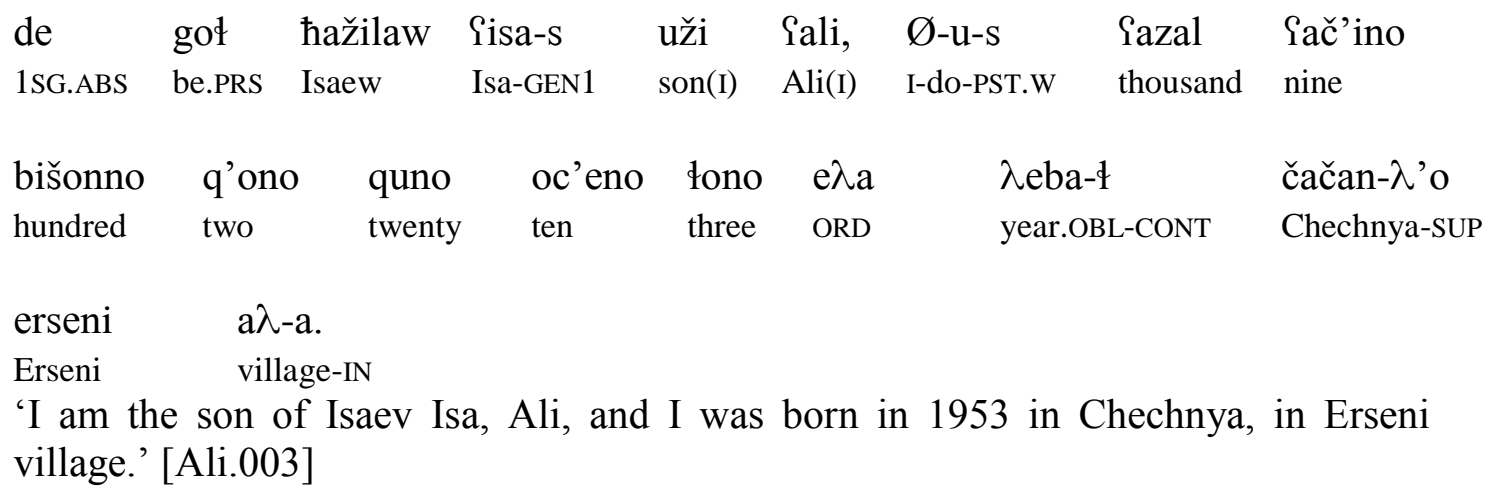

${ }^{6} \mathrm{Cf}$. Akhvakh, where in such contexts a verb form is used that implies not only direct evidence but also active involvement of the speaker in the event (D. Creissels, p.c.). 
(27) Tsez

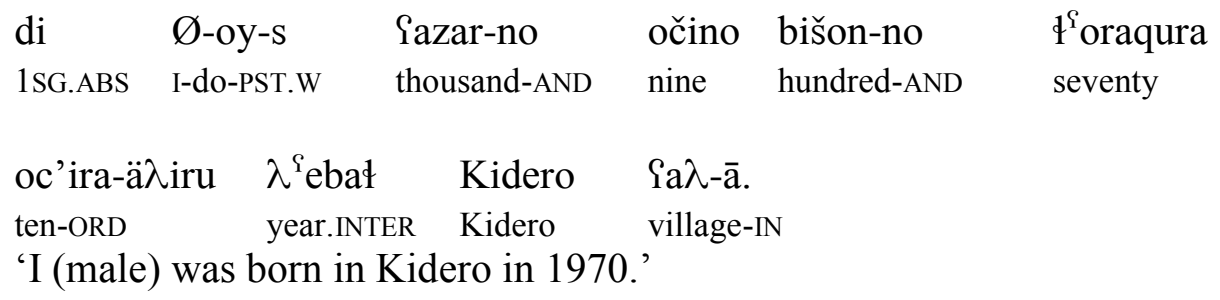

In fictional narratives, e.g. in tales, the Past unwitnessed form is used to start the sentence which corresponds to English 'Once upon a time' (28a, 29, 30). The narrative particle is most often used in this context, i.e. this particle is used in the first sentence of a tale $(28 \mathrm{a}, 29)$ and it may also occur throughout the narration, as in (28b).

(28) Khwarshi
Ø-eč-un-ay- $\lambda$ o
I-be-PST.UW-NEG-NARR
hos
$\begin{array}{ll}\text { mičaha-W } & \text { Žik’o. } \\ \text { rich-I } & \operatorname{man}(\mathrm{I})\end{array}$
a. Ø-eč-un- $\lambda$ o
I-be-PST.UW-NARR

'Once upon a time there was a rich man.' [Sisters.001]
b. iso y-eč-un- $\lambda$ o hono $\mathrm{kad}$.
that.GEN1 II-be-PST.UW-NARR three girl(II)

'He had three daughters.' [Sisters.002]

(29) Tsez

$\begin{array}{llcll}\begin{array}{l}\text { Zow-n- } \lambda \text { ax } \\ \text { be-PST.UW-NARR }\end{array} & \begin{array}{l}\text { zow-n-anu- } \lambda \text { ax } \\ \text { be-PST.UW-NEG-NARR }\end{array} & \begin{array}{l}\text { eni.babiw-n } \\ \text { parents-AND }\end{array} & \begin{array}{l}\text { žedu-S-gon } \\ \text { 3PL-GEN1-PART }\end{array} \\ \begin{array}{llcl}\text { sis-tow } & \text { sis } & \text { uži-n. } & \\ \text { one-EMPH } & \text { one } & \text { son-AND } & \end{array}\end{array}$

'Once upon a time there was a couple who had only one son.' [Fisherman.001]

(30) Hinuq

$\begin{array}{llll}\text { a. hes } & \text { zoq'we-n } & \text { rwadi. } \\ & \text { one } & \text { be-PST.uw } & \text { raven(III) }\end{array}$

'Once upon a time there was a raven.' [gvadi.zeru.001]
b. b-i $\lambda^{\prime} i-n, \quad$ rek'uzas r-ik'ek'-no cenno b-i $\lambda$ 'i-n,
III-go-PFV.CVB person.OBL.PL.GEN1 V-steal-PFV.CVB brynza(v) III-go-PFV.CVB
$\begin{array}{lll}\text { ažey-žo } & \text { al- } \lambda \text { 'o-n } & \text { b-iči-n. } \\ \text { tree-GEN2 } & \text { branch-SUP-AND } & \text { III-sit-PST.UW }\end{array}$
'Having stolen cheese from some men, it flew and sat on the branch of the tree.' [gvadi.zeru.002]


(31) Tsez

$\begin{array}{lllll}\text { ned- } \lambda \text { 'ay } & \text { soder } & \text { neła.neła-s } & \text { xexoy } & \text { kiki-x } \\ \text { that.OBL-SUPER.ABL } & \text { after } & \text { REFL-GEN1 } & \text { young.animal } & \text { feed-cVB }\end{array}$

bercingo aүi-n b-ič-in.

good bird(III)-AND III-be-PST.UW

'After that, it fed its nestling and was a good bird.' [Bird and fox.020]

In Tsez it is very frequent that after starting with the Past unwitnessed form (32a, 33a), the speaker switches to either the Present tense (32b) or to the Past witnessed tense (33b). From the corpus study discussed in Comrie \& Polinsky (2007) it is concluded that the Past witnessed functions like a historic present (i.e. the present tense used with past time reference), thus adding vividness to the description of the past event.

(32) Tsez

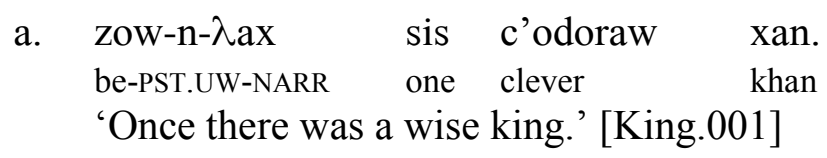

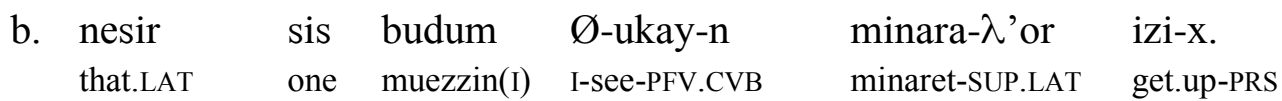

'He saw a muezzin getting up the minaret.' [King.002]

(33) Tsez (Comrie et al. 2007: 346)
a. sis zew-n uži-n, kid-no c'aq'-tew
one be-PST.UW boy-AND girl-AND very-EMPH
sid-är sis b-et-äsi.
one-LAT one HPL-love-RES

'There was a boy and a girl who loved one another very much.' [Sentence1]
b. sidaqui kibd-ä $\mathrm{e} \lambda \mathrm{i}-\mathrm{s} \quad$ nesi $\mathrm{z} \overline{\mathrm{o}}$-qo-r ...
once girl-ERG say-PST.w that.OBL boy-POSS-LAT
'One day the girl said to that boy...' [Sentence2]

The past unwitnessed forms can also have inferential meaning, and it refers to an inference made by the speaker on the basis of direct evidence; the speaker sees the chopped meat, and makes the inference that the father has slaughtered the sheep.

(34) Khwarshi

\begin{tabular}{|c|c|c|}
\hline $\begin{array}{l}\text { obu-t'-i } \\
\text { father-OBL-ERG }\end{array}$ & $\begin{array}{l}\text { bì } \lambda{ }^{\prime} q^{\prime} u \\
\text { sheep(III) }\end{array}$ & $\begin{array}{l}\text { b-ux }{ }^{\mathrm{Q}} \text { ad-in. } \\
\text { III-slaughter-PST.UW }\end{array}$ \\
\hline
\end{tabular}


(35) Tsez

k'et'ā c'ik'iw $\gamma^{\complement}$ ay ha入-un šit'u-räy.

cat.ERG all milk drink-PST.UW plate.IN.ABL

'The cat drank all the milk from the plate.' (the speaker sees the cat's empty plate)

(36) Hinuq

[Looking out of the window, and seeing that the ground is wet]

qema r-aq'e-n.

$\operatorname{rain}(\mathrm{v}) \quad \mathrm{V}$-come-PST.UW

'It (apparently) rained.' [Mag.059]

\subsection{Expressing mirativity}

Mirative overtones, which indicate new and unexpected information, can be expressed with the unwitnessed forms combining only with the first person, and this refers to a situation of which the speaker is not conscious or to a situation in which the speaker suddenly realizes something as a surprise. It is interesting that mirative overtones most often occur in a negative context, maybe expressing the speaker's surprise at some facts that did not meet his/her expectations (though positive forms are not excluded for a mirative reading). This is illustrated by example (37) from Khwarshi in which the main hero surprisingly discovers (after lying on the ground and preparing himself to die) that he is not actually dead. The particle - $k o$ also contributes to such an interpretation as it expresses surprise.

(37) Khwarshi

\begin{tabular}{|c|c|c|c|c|}
\hline $\begin{array}{l}\text { Malla.rasan } \\
\text { Malla.rasan(I) }\end{array}$ & $\begin{array}{l}\text { Ø-ah-un } \\
\text { I-stand-PFV.CVB }\end{array}$ & $\begin{array}{l}\text { hobołe } \\
\text { that.oBL }\end{array}$ & $\begin{array}{l}\text { mok'o } \lambda \text { 'ozi, } \\
\text { place.SUP.ABL }\end{array}$ & $\begin{array}{l}\check{z} \mathrm{u} \\
\text { that.ABS }\end{array}$ \\
\hline $\begin{array}{l}\text { Ø-ečč-u, } \\
\text { I-be-PST.PTCP }\end{array}$ & 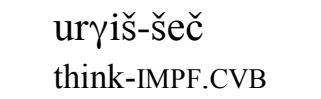 & $\begin{array}{l}\emptyset \text {-uh-un- } \lambda \text { in } \\
\text { I-die-PFV.CVB-QUOT }\end{array}$ & $\begin{array}{l}\text { hed } \\
\text { then }\end{array}$ & $\begin{array}{l}\text { i } \lambda \text {-in } \\
\text { say-PST.UW }\end{array}$ \\
\hline do & $\varnothing$-uh-un & eč-un-ay-ko. & & \\
\hline 1SG.ABS & I-die-PFV.CVB I-be & E-PST.UW-NEG-INT & & \\
\hline
\end{tabular}

\subsection{Negation}

The contrast between witnessed and unwitnessed evidentials is also the same in negative clauses, which means that negative evidentials also specify the source of the information. Witnessed and unwitnessed forms have corresponding negative markers, summarized in Table 1. Note that the negative indirect evidential marker in Khwarshi is attached directly to the suffix of the Past unwitnessed, i.e. it is used to negate with the Past unwitnessed tense (39), and the Hinuq negative suffix for direct evidence is added directly to the past witnessed form (42). As was mentioned above, in Tsez and Hinuq indirect evidential forms are synthetic when affirmative, and the negative indirect forms always require a negative Present tense copula. 


\begin{tabular}{|c|c|c|c|c|c|c|}
\hline & Khwarshi & Tsez & Hinuq & Bezhta & Hunzib \\
\hline \multirow{2}{*}{$\begin{array}{c}\text { direct } \\
\text { evidential }\end{array}$} & affirmative & $-\mathrm{i}$ & $-\mathrm{si}$ & $-\check{\mathrm{s}}$ & -yo & $-(\mathrm{V}) \mathrm{r}$ \\
\hline & negative & -bi & - č’u $^{\prime}$ & - me & -e?eš & $-i \check{S}$ \\
\hline \multirow{2}{*}{$\begin{array}{l}\text { indirect } \\
\text { evidential }\end{array}$} & affirmative & -un & - no & - no & CVB+gey & $\mathrm{CVB}+\mathrm{lo} / \mathrm{li}$ \\
\hline & negative & -ay & CVB+anu & $\mathrm{CVB}+\mathrm{gom}$ & CVB+ gä?ä & CVB+ gač \\
\hline
\end{tabular}

Table 1: Affirmative and Negative evidential forms

(38) Khwarshi - negative witnessed

$\begin{array}{llllll}\text { diyo } & \text { lok'o } & \text { l-eč-bi } & \text { dudu-n } & \text { bit'ura-l } & \text { is-bič. } \\ \text { 1SG.GEN1 } & \text { heart(IV) } & \text { IV-be-NEG.PST.W } & \text { how-AND } & \text { right-IV } & \text { say-NEG.CVB } \\ \text { 'My heart } & \text { didn't stop beating fast until I told the truth } & \text { [Fool.058] } & \end{array}$

'My heart didn't stop beating fast until I told the truth.' [Fool.058]

(39) Khwarshi - negative unwitnessed

obu-t'-i q'ala šuk'-un-ay.

father-OBL-ERG children beat-PST.UW-NEG

'Apparently, the father did not beat (his) children.'

(40) Tsez (Comrie \& Polinsky 2007: 345) negative witnessed

elo-n āy e $\lambda$ i-x $\quad$ zow-č'u.

there-AND no say-IMPF.CVB be-NEG.PST.W

'He didn't refuse there.'

(41) Tsez - negative unwitnessed

$\begin{array}{llll}\text { dey } & \text { esiw } & \varnothing \text {-ay-n } & \text { anu. } \\ \text { 1sG.GEN1 } & \text { brother(I) } & \text { I-come-PFV.CVB } & \text { be.NEG }\end{array}$

'My brother did not come.'

(42) Hinuq - negative witnessed

xex-za-łes sedi-qen t'ek t'ot'er-iš-me.

child-OBL.PL-CONT.ABL one.ERG-NEG book read-PST.W-NEG

'None of the children read the book.'

(43) Hinuq - negative unwitnessed

kidili a $\lambda$-a-r $\quad \varnothing$-i $\lambda$ 'i-n gom.

Kidero village-IN-LAT I-go-PFV.CVB be.NEG

'He did not go to Kidero village.'

(44) Hunzib (van den Berg 1995: 84) negative witnessed

ož-di-1 quw-iš t'ex̌.

boy-OBL-ERG read-PRET.NEG book

'The boy did not read the book.' 
(45) Hunzib - negative unwitnessed

ož-di-1 $\quad x \dot{i} \lambda u \quad$ gix-un qač'.

boy-OBL-ERG trousers put.on-PFV.CVB be.NEG

'The boy didn't put on his trousers.'

(46) Bezhta - negative witnessed

woy $\quad$ xo $\quad$-üq-e?eš.

dog.ERG meat(IV) IV-eat-PRET.NEG

'The dog didn't eat the meat.'

(47) Bezhta - negative unwitnessed

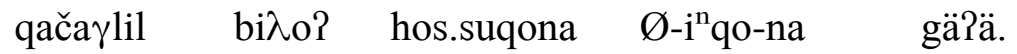

bandit.DAT house.IN none I-find-PFV.CVB be.NEG

'Apparently the bandit did not find anyone at home.'

\section{The Reported Evidential}

The reported evidential refers to information that was learned from someone else. Tsezic languages use special particles to indicate reported evidentials. West Tsezic has two separate particles, one for quotative use (Khwarshi $-\lambda i n$, Tsez $-\lambda i n$, Hinuq $-\lambda e n$ ) and one for narrative use (Khwarshi - $\lambda o$, Tsez - $\lambda a x$, Hinuq - e $\lambda$ ), whereas East Tsezic has one particle (Bezhta $-\lambda o$, Hunzib $-\lambda e$ ) for quotative and narrative usage.

The meanings of reported evidentials and reported speech are closely related. Reported speech refers to information heard from someone else, and it is always marked with the quotative particles.

The Tsezic quotative particles are used to indicate reported evidential and reported speech. In Tsezic the quotative particle (Khwarshi - $\lambda i n$, Tsez - $\lambda$ in, Hinuq - $\lambda$ en, Bezhta $-\lambda o$, Hunzib - $\lambda e$ ) comes from the grammaticalized Perfective converb 'having said' (although in East Tsezic the current meaning of the verb is 'to shout'). To introduce a reported speech utterance, a verb of speech is used and the quotative particle always follows the last word of the reported speech, i.e. marking the end of the reported utterance.

(48) Khwarshi

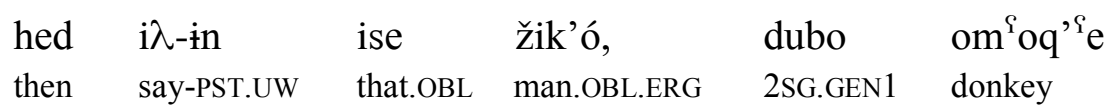

hono-lux $\quad{ }^{\mathrm{Q}} \overline{\mathrm{n}}^{\mathrm{n}} \overline{\mathrm{o}}^{\mathrm{n}} \lambda$-a $\lambda \mathrm{a}$, mo $\quad$-uh-a goli- $\lambda$ in.

three-REPET bray-ANTR 2SG.ABS I-die-INF be.PRS-QUOT

'Then that man said, "You will die when your donkey brays three times."-' [Malla rasan]

(49) Tsez

neła esir-no šebi deber r-oq-no, šida mi šiq ${ }^{\text {o }}$ onyayx- $\lambda$ in. it.ERG ask-PST.UW what 2SG.LAT IV-happen-PST.UW why 2SG.ABS limp.PRS-QUOT 'He asked, "What happened to you, why are you limping?"-' [Aliqilich.159] 
(50) Hinuq

$\begin{array}{lllll}\text { seda } & \mathrm{a} \lambda \text {-a-zo } & \text { rek'u-y } & \text { e } \lambda \text { i-n } & \text { de } \\ \text { one.OBL } & \text { village-OBL-GEN2 } & \text { person.OBL-ERG } & \text { say-PST.Uw } & \text { 1sG.ABS }\end{array}$

Malla.nasrudin-qo $\quad \mathrm{a} \lambda$ 'ir-a $\quad \varnothing$-ič-amin- $\lambda$ en.

Malla.nasrudin-POSS deceive-INF I-become-FUT1.NEG-QUOT

'One village man said, "Malla Nasrudin cannot fool me." ' [Nasrudin.003]

(51) Hunzib (van den Berg 1995: 257)

\begin{tabular}{|c|c|c|c|c|}
\hline $\begin{array}{l}\text { bo } \lambda \mathrm{u}-\mathrm{S} \\
\text { this.OBL-GEN1 }\end{array}$ & $\begin{array}{l}\text { hi }^{\mathrm{n}} \text { ya-d } \\
\text { blood.OBL-INST }\end{array}$ & $\begin{array}{l}\text { r-əc'-ər.u } \\
\text { V-be.filled-PST.PTCP }\end{array}$ & $\begin{array}{l}\text { lač'i } \\
\text { clothes(V) }\end{array}$ & $\begin{array}{l}\text { r- } \alpha q^{\prime}-o \\
\text { V-bring-IMP }\end{array}$ \\
\hline $\operatorname{di} i \mathrm{i}-\lambda \mathrm{e}$ & nisə-n. & & & \\
\hline G.DAT-QUOT & say-PFV.CVB & & & \\
\hline
\end{tabular}

(52) Bezhta

holco načalniki-ya niso-na gey ali-qa ho ${ }^{\mathrm{n}} \mathrm{s}-\mathrm{coy}-\mathrm{s} \quad$ öžö

that.OBL chief-OBL.ERG say-PFV.CVB be.PRS Ali-POSS one-DISTR-GEN1 boy

dibo gey, hon ${ }^{\mathrm{s}}$-coy-s öžö dil niso-na.

1SG.GEN1 be.PRS one-DISTR-GEN1 boy(I) 1SG.DAT I-become-FUT-QUOT say-PFV.CVB

"The chief said to Ali, "You have one of the boys, and I will have another boy.",

The hearsay construction with the meaning 'they say' in West Tsezic is based on particles which are often used in narratives: Khwarshi $-\lambda o$, Tsez - $\lambda a x$, Hinuq $-\mathrm{e} \lambda$. So these particles mark information that was acquired from someone else.

The West Tsezic quotative particles can never be used in this context (as in 53 and 54), i.e. the quotative particles should always be accompanied by some utterance verb. As for East Tsezic, the same particle is used for quotation and narration (55).

(53) Tsez

žin č’agu yoł- $\lambda$ ax ža baharči.

today alive be-NARR he brave.young.man

'They say he is still alive.' [Wooden_horse.059]

(54) Khwarshi
a. iso
Samal
žuka- $\lambda$ o
b-eč-i.
he.GEN1
character(III) bad-NARR
III-be-PST.W

'He had a bad character, they said.' (the speaker heard this from the person who saw this event) 

b. iso
Samal
žuka- $\lambda$ o
b-eč-un.
he.GEN1
character
bad-NARR
III-be-PST.UW

'He apparently had a bad character, they said.' (the speaker heard this from the person who did not see this event)

(55) Bezhta

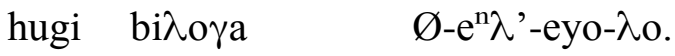

he house.NEAR I-go-PST.W-QUOT

'He went home, they said.'

Another way to express the hearsay meaning is to omit the subject of the utterance verb, i.e. this construction has an unspecified subject. This construction is simply based on the utterance predicate and the quotative particle.

(56) Tsez

$\begin{array}{llllll}\text { c'i } & \text { rik'asi } & \text { keč'oqan } & \varnothing \text {-ay-X- } \lambda \text { in } & \text { e } \lambda \text { i-X } & \text { išk'olār. } \\ \text { name } & \operatorname{man}(\mathrm{I}) & \text { singer } & \text { I-come-PRS-QUOT } & \text { say-PRS } & \text { school.IN.LAT }\end{array}$

'(They) say the famous singer will arrive at (our) school.'

(57) Bezhta

$\begin{array}{lllllll}\text { niso-s, } & \text { maxačkalali? } & \text { bež }{ }^{\prime} \text { a- } \gamma \mathrm{a} & \text { ho }^{\mathrm{n}} \mathrm{s} & \text { wodo } & \text { äydää } & \text { q'urban } \\ \text { say-PRS } & \text { Makhachkala.IN } & \text { Bezhta-NEAR } & \text { one } & \text { day } & \text { early } & \text { Kurban }\end{array}$

wodo $\quad \mathrm{y}-\overline{\mathrm{o}}-\mathrm{s}-\lambda_{\mathrm{o}} \quad$ niso-na.

day(IV) IV-do-PRS-QUOT say-PFV.CVB

'(They) say, the Kurban holiday is celebrated in Makhachkala one day earlier than in Bezhta.'

In Khwarshi the hearsay construction can also be formed with the fossilized verb $\check{c}^{\prime} \bar{a} l$ in the General tense, derived from the affective verb č'ala 'to inform, to hear'. Constructions with $\check{c}$ ' $\bar{a} l$ mean 'they say'. This construction is possible with present time reference (58) and past time reference, and when it has past time reference, only indirect evidential forms can be used (59) and never direct evidentials.

(58) Khwarshi

$\begin{array}{llll}\text { ise } & \text { mašina } & \text { b-esse } & \text { č'āl. } \\ \text { that.OBL.ERG } & \text { car(III) } & \text { III-buy.PRS } & \text { inform.GNT }\end{array}$

'They say he is buying a car.'

(59) Khwarshi

ise mašina b-ez-un č’āl.

that.OBL.ERG car(III) III-buy-PST.UW inform.GNT

'They say he bought a car.' 


\section{Questions and Evidentials}

Interrogative clauses have the same set of evidential forms as declarative clauses, i.e. direct and indirect evidentials can be used in questions. Evidentials in interrogative clauses refer to the source of information of the hearer/addressee, but not to the information source of the speaker, i.e. the direct evidential can be used in questions when the addressee is the indicated source of information, where he or she is a direct witness to the event in question. Sentence (60) illustrates the following situation: speaker A knows that speaker B was at the wedding, i.e. speaker A's information source is the addressee (or speaker B).

(60) Khwarshi

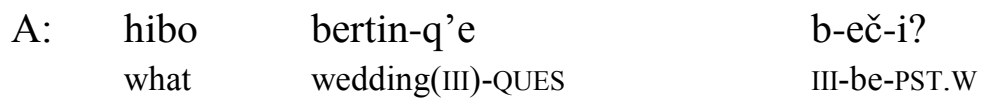

'How was the wedding?'

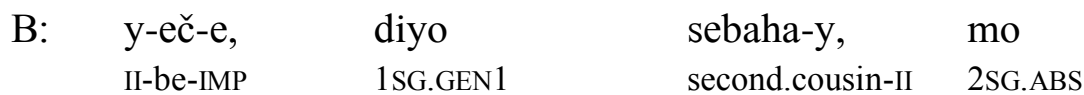

y-eč-bi-ko bertino $\lambda$ 'o-?

II-be-NEG.PST.W-INT wedding.SUP

'Wait, my sister, haven't you been to the wedding?' [Dialog]

(61) Bezhta

$\begin{array}{llll}\text { A: } & \text { iyo } & \text { ken } & \text { y-ō-yo-di? } \\ & \text { mother.ERG } & \text { meal(IV) } & \text { IV-do-PRET-QUES }\end{array}$

'Did the mother cook the meal?'

B: $\quad \mathrm{Sin}^{-\mathrm{n}}, \quad \mathrm{y}-\overline{\mathrm{o}}-\mathrm{yo}$.

yes IV-do-PRET

'Yes, she cooked it.'

The indirect evidential form in questions also corresponds to the information source of the addressee. The use of the indirect evidential is based on the speaker's assumption that the addressee has also witnessed the event indirectly.

(62) Hinuq

$\begin{array}{llll}\text { A: } & \text { hayłoy } & \text { bu } \lambda \mathrm{e} & \text { b-u-n-e? } \\ & \text { he.ERG } & \text { house(III) } & \text { III-do-PST.UW-QUES }\end{array}$

'Did he build the house?'

B: b-u-n.

III-do-PST.UW

'Yes, he did.' 
(63) Tsez
A: iћā
†ä $\lambda$,
bero
b-ik'-in-ā-?
river.IN
water.SUP ice(III)
III-go-PST.UW-QUES

'Did the ice cover the river?'

B: hudu, b-ik'-in.

yes III-go-PST.UW

'Yes, it did.'

(64) Hunzib (van den Berg 1995: 165)

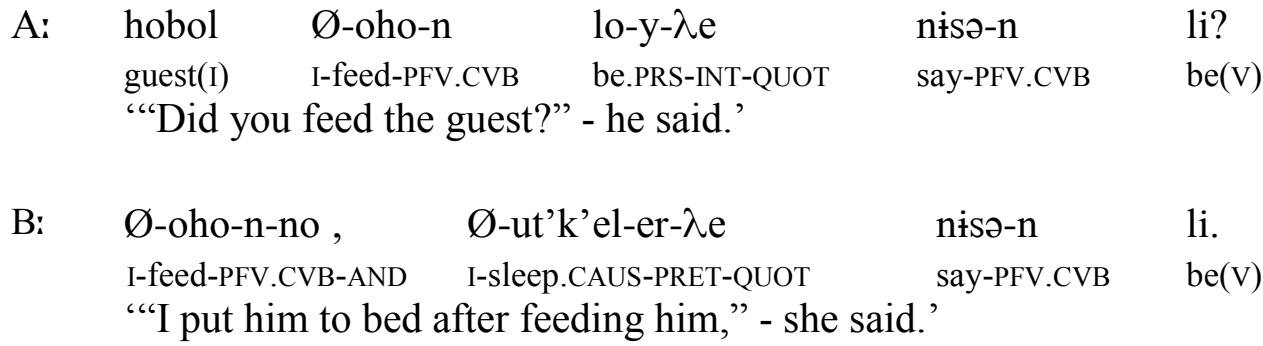

\section{Discussion on Perfect and Resultative}

The East Tsezic Perfect (which is an analytical form) has two main functions: it is used to refer to perfect events (in this function the copula is obligatorily used) and it is used to mark indirect evidence (in this function the copula can be optionally omitted in Bezhta).

The Perfect in West Tsezic has developed further. The development of the West Tsezic Perfect is a development of both meaning and form. While East Tsezic has one verbal form to convey two meanings, indirect evidence and perfect, West Tsezic has developed two separate verbal forms, one for evidential and the other for perfect.

The evidential form in West Tsezic, which is a synthetic form, is only used for indirect evidence (and never for perfect), i.e. indirect evidential forms express a dynamic situation in the past not witnessed by the speaker, but not a stative situation in the present.

Thus, East Tsezic presents the earliest stage, with an analytical construction both in affirmative and negative forms, though in Bezhta the affirmative indirect evidential optionally occurs without the present tense copula. In West Tsezic the affirmative indirect evidential is a synthetic form, and the negative indirect evidentials are formed differently. Khwarshi uses a special negative suffix added to the form of the indirect evidential. Tsez has two constructions to express the negative indirect evidential, and they are dialectally conditioned. Tsez has about five main dialects: three dialects form the negative indirect evidential with the analytical construction (perfective converb plus negative copula), whereas other dialects (the Asakh and Shapikh dialects) use the dedicated suffix for negation of the indirect evidential (i.e. use a synthetic form) (Imnajšvili 1963: 198). The Hinuq negative indirect evidential is formed with the perfective converb plus the negative present tense copula. So, in negative forms in Tsez and Hinuq one can detect traces of an earlier analytical form of the indirect evidential.

The other construction in West Tsezic is a resultative construction which is an analytical form. The formation of this construction varies in West Tsezic. In Khwarshi it is based on the perfective converb and the Present tense copula. The Khwarshi Resultative is a productive construction used with all but a few verbs (e.g. 'to want', 'to believe'). The resultative 
construction in Tsez and Hinuq is an innovation not formally related to the other constructions, and it is based on the dedicated resultative participle and the Present tense copula. Table 2 summarizes the development of the Tsezic perfect.

The development of anterior or resultative into evidentials of indirect evidence is well-known in Turkish, Bulgarian, Macedonian, and Georgian (Bybee at el. 1994:95).

Tsezic data illustrate the general evolution starting from resultative constructions to prototypical perfects and from perfects to forms also used to express evidentiality.

\begin{tabular}{|c|l|l|l|l|c|}
\hline & \multicolumn{2}{|c|}{ East Tsezic } & \multicolumn{3}{c|}{ West Tsezic } \\
\cline { 2 - 6 } & \multicolumn{1}{|c|}{ Hunzib } & \multicolumn{1}{c|}{ Bezhta } & \multicolumn{1}{c|}{ Khwarshi } & Hinuq \\
\hline $\begin{array}{l}\text { Past } \\
\text { Unwitnessed }\end{array}$ & & & & & \\
\hline AFF. & CVB+COP & CVB(+COP) & CVB & CVB & CVB \\
\hline NEG. & CVB+NEG.COP & CVB+NEG.COP & NEG.CVB & $\begin{array}{l}\text { NEG.CVB/ } \\
\text { CVB+NEG.COP }\end{array}$ & CVB+NEG.COP \\
\hline Perfect & & & & & \\
\hline AFF. & CVB+COP & CVB+COP & CVB+COP & RES.PTCP+COP & RES.PTCP+COP \\
\hline NEG. & CVB+NEG.COP & CVB+NEG.COP & $\begin{array}{c}\text { CVB+ } \\
\text { NEG.COP }\end{array}$ & $\begin{array}{c}\text { RES.PTCP+ } \\
\text { NEG.COP }\end{array}$ & $\begin{array}{c}\text { RES.PTCP+ } \\
\text { NEG.COP }\end{array}$ \\
\hline
\end{tabular}

Table 2: Development of Tsezic perfect

\section{Conclusion}

The system of evidentiality in Tsezic languages shows the contrast between the witnessed and unwitnessed events expressed only in the past tense. In West Tsezic languages this contrast between witnessed and unwitnessed is expressed with morphologically simple past witnessed and past unwitnessed forms. In East Tsezic languages this contrast of witnessed and unwitnessed events is based on the distinction between a morphologically simple past tense (Preterite) and the Perfect, which is a compound tense based on the perfective converb and the Present tense copula.

Therefore, the main distinction is made between a visual and non-visual source of information, but the choice between evidential forms also depends on whether or not the speaker remembers the event.

\section{Acknowledgment:}

I would like to thank Bernard Comrie and two anonymous reviewers for comments and suggestions that improved my paper very much.

\section{Abbreviations}

$\mathrm{I}-\mathrm{V}$ - gender markers, ABL - Ablative, ABS - Absolutive, ANTR - anterior (converb), CONT Contessive, EMPH - emphatic, GNT - General tense, HPL - human plural, IMPF.CVB - imperfective converb, IN - Inessive, INF - infinitive, INST - instrumental, INT - intensifier, INTER - Interessive, LAT - Lative, MSD - masdar, NARR - narrative, NHPL - non-human plural, OBL - Oblique, ORD ordinal, PRET - preterite, PST.W - Past witnessed, PST.UW - Past unwitnessed, PST.PTCP - Past participle, PFV.CVB - Perfective converb, QUES - question, QUOT - Quotative, REFL - reflexive, REPET - repetitive, RES - resultative, SUP - Superessive, TEMP - temporal (converb), TRANSL Translative, VERS - Versative. 


\section{References}

Aikhenvald, Alexandra. 2004. Evidentiality. Oxford: Oxford University Press.

Aikhenvald, Alexandra and Robert M. W. Dixon. 2003. Studies in evidentiality. Amsterdam: John Benjamins.

Bokarev, Evgenij A. 1959. Cezskie (didojskie) jazyki Dagestana. Moskva: Izd-vo AN SSSR.

Bybee, Joan, Revere Perkins and William Pagliuca. 1994. The evolution of grammar: tense, aspect, and modality in the languages of the world. Chicago: University of Chicago Press.

Comrie, Bernard and Maria Polinsky. 2007. Evidentials in Tsez. Le traitement épistémologique de l'information: illustrations amérindiennes et caucasiennes, ed. by Zlatka Guentchéva \& Jon Landaburu, 335-350. Louvain etc.: Peeters.

De Haan, Ferdinand. 1999. Evidentiality and epistemic modality: Setting boundaries. Southwest Journal of Linguistics 18/83-101.

De Lancey, Scott. 1997. Mirativity: The Grammatical Marking of Unexpected Information. Linguistic Typology 1/33-52.

Friedman, Victor. 1986. Evidentiality in the Balkans: Bulgarian, Macedonian, and Albanian. Evidentiality: the linguistic coding of epistemology, ed. by Wallace Chafe and Johanna Nichols, 165-187. Norwood, N.J.: Ablex.

Imnajšvili, David S. 1963. Didojskij jazyk: v sravnenii s ginuxskim i xvaršijskim jazykami. Tbilisi: Izd-vo Akademii Nauk Gruzinskoj SSR.

Johanson, Lars and Bo Utas (eds.) 2002. Evidentials: Turkic, Iranian and neighboring languages. Berlin-New York: Mouton de Gruyter.

Khalilova, Zaira. 2009. A grammar of Khwarshi. Utrecht: LOT.

Kibrik, Alexander E. (ed.). 2001. Bagvalinskij jazyk: grammatika, teksty, slovari. Moskva: Nasledie.

Klimov, Georgij A. 1978. Strukturnye obscnosti kavkazskich jazykov. Moskva: Nauka.

Nedjalkov, Vladimir P. \& Sergei J. Jaxontov. 1988. The typology of resultative constructions. Typology of resultative constructions, ed. by Vladimir Nedjalkov, 3-62. Amsterdam: John Benjamins.

Tatevosov, Sergey. 2001. From resultatives to evidentials: Multiple uses of the Perfect in NakhDagestanian languages. Journal of Pragmatics 33/443-464.

van den Berg, Helma. 1995. A grammar of Hunzib (with texts and lexicon). München/ Newcastle: Lincom Europa.

Willett, Thomas. 1988. A Cross-Linguistic Survey of the Grammaticalization of Evidentiality, Studies in Language 12/51-97.

Author's Contact Information:

Zaira Khalilova

Max Planck Institute for Evolutionary Anthropology, Leipzig

khalilova@eva.mpg.de 